Pogranicze. Studia Spoleczne. Tom XXVIII (2016)

DOI 10.15290/pss.2016.28.08

RENATA TANAJEWSKa

WYdZIAE PRAWA

UNIWERSYTET W BIAŁYMSTOKU

E-MAIL: RENATA.TANAJEWSKA@GMAIL.COM

\title{
NIE PAMIĘTAM DOKĄD IDĘ, ALE WIEM, ŻE JESTEM - O ZDOLNOŚCI DO CZYNNOŚCI PRAWNYCH OSÓB Z ZABURZENIAMI PAMIĘCI I ŚWIADOMOŚCI
}

Występowanie zaburzeń pamięci i świadomości pamięci to coraz powszechniejszy problem współczesnego społeczeństwa. Trudno jest jednoznacznie wskazać ich przyczyny. Zaburzenia pamięci i świadomości najczęściej występują u osób starszych, głównie powyżej 65 roku życia. Zaburzenia pamięci i świadomości wiążą się z następującymi chorobami: Alzheimera [http://wiadomosci.onet.pl/prasa/pieklo-zwane-alzheimer/cbedl, 2015], Parkinsona [Kozubski, Liberski, 2006: 282-286; Jankovic, 2008: 368-376], Picka [Onari, Spatz, 1926: 470-511], pląsawica Huntingtona [Szczeklik, 2005: 1939-1940; Kozubski, 2006: 254-255; Kozubski, 2004: 363-364], neuroborelioza [Zajkowska, Hermanowska-Szpakowicz, Grygorczuk, Kondrasik, Pancewicz, Czeczuga, Ciemerych, 2006: 13-21] oraz CreutzfeldtaJakoba [Liberski, 2003: 372-385; Liberski, 2006: 414-423; Kordek, Bratosiewicz-Wąsik, Grams, Liberski, 2003: 117-162.]. W odniesieniu do prawa cywilnego zagadnienie zaburzeń pamięci i świadomości jest istotne pod względem ważności oświadczenia woli i dokonanej czynności prawnej w związku z takim oświadczeniem woli. Problem można zobrazować posługując się przykładem natury filozoficznej: konstrukcją stołu. „Dla oka jest on prostokątny, brązowy i błyszczący, dla dotyku gładki, zimny i twardy; gdy w niego stukam, wydaje głuchy dźwięk" [Russell, 2012: 11]. Zwykle nie analizuje się konstrukcji stołu, każdy przyjmuje, że stół ma pasować do otoczenia, do krzeseł w jadalni, do koloru podłogi w kuchni, do komody w gabinecie. Tak bardzo doświadcza się potrzebę istnienia stołu, że przestaje się dostrzegać jego fizyczność. Jednak, czy stojąc dwa metry od stołu 
z zamkniętymi oczami i obracając się, nawet jednokrotnie, wokół własnej osi, istnieje możliwość wskazania dokładnego położenia stołu bez otwarcia oczu? Czy z zamkniętymi oczami i nie dotykając stołu można stwierdzić, jakiego koloru, kształtu, czy z jakiego tworzywa wykonany jest stół? Konstrukcja stołu znana jest przez doświadczenie i wnioskowanie. Doświadczamy zmysłami, a wnioskujemy z uzyskanego doświadczenia bądź posiadanej wiedzy. Jeżeli zatem umysł uniemożliwia doświadczanie i wnioskowanie, jaka jest rzeczywistość? Czy stół naprawdę istnieje? [Russell, 2012]. Analizując przedstawiony przykład należy zadać pytanie, czy osoba z zaburzeniami pamięci i świadomości, nie jest tą, która próbuje określić status stołu. Jej zmysły nie pracują w sposób prawidłowy, dostarczając umysłowi błędne doświadczenie, w konsekwencji czego jej wnioskowanie często obarczone jest błędem. Wracając na grunt prawa, osoba taka dokonuje czynności prawnych, może być świadoma ich dokonywania, ale nieświadoma skutków prawnych dokonania. Osoba z zaburzeniami pamięci i świadomości może w chwili dokonywania czynności prawnej mieć wolę jej dokonania, a po jej dokonaniu oświadczyć, że nie pamięta chwili jej dokonania lub nie wyraziła zgody na jej dokonanie. $Z$ drugiej zaś strony osoba ta może potwierdzić zgodność oświadczenia woli $\mathrm{z}$ dokonaną czynnością prawną, ale osoba trzecia może kwestionować dokonanie czynności prawnej, np. z powodu swojego pokrzywdzenia dokonaną czynnością prawną. Zatem stawia się pytanie, gdzie jest granica pamięci i świadomości ludzkiego umysłu? Czy istnieje możliwość precyzyjnego wskazania okresu prawidłowego funkcjonowania pamięci, czy bycia świadomym? Czy pamięć i świadomość stanowią obligatoryjne elementy oświadczenia woli przy dokonywaniu czynności prawnych? Czy samo stwierdzenie występowania zaburzeń pamięci i świadomości wystarczy, aby uznać czynność prawną za nieważną?

Celem artykułu jest wskazanie problemu rozumienia dokonywanych czynności prawnych przez osoby z zaburzeniami pamięci i świadomości oraz stanowi próbę ustalenia granicy pomiędzy czynnościami ważnymi i nieważnymi z powodu pojawienia się zaburzeń pamięci i świadomości.

Przy opracowaniu stawianego problemu wykorzystano dogmatyczną metodę badawczą, analityczną metodę badawczą oraz analizę orzecznictwa. Metoda dogmatyczna została wykorzystana w taki sposób, że poddano analizie przepisy kodeksu cywilnego w zakresie zasad dokonywania czynności prawnych. Metoda analityczna polegała na przeglądzie naukowych opracowań i poglądów przedstawicieli doktryny w zakresie poruszanego zagadnienia. 
Najczęstszym powodem zaników pamięci czy świadomości jest choroba Alzheimera, która najczęściej przybiera postać otępienia. Jest to choroba neurodegeneracyjna, nieuleczalna, postępująca i prowadzi do śmierci pacjenta. Po raz pierwszy została opisana przez niemieckiego neuropatologa Alois Alzheimera w 1906. W następstwie dokonań naukowych choroba została nazwana jego nazwiskiem [Berchtold, Cotman, 1998: 173-189]. Jej występowanie najczęściej stwierdza się w grupie wiekowej osób po 65. roku życia, jednakże możliwe jest jej pojawienie się także wcześniej [Brookmeyer, Gray, Kawas, 1998: 1337]. W 2006 roku odnotowano na świecie ok. 26,6 miliona osób cierpiących na tę chorobę. Zgodnie z przewidywaniami naukowców z zakresu medycyny w 2050 roku dotknie ona jedną na 85 osób [Brookmeyer, Johnson, Ziegler-Graham, Arrighi, 2007: 186-191].

Choroba u każdego pacjenta przebiega w odmienny sposób. Natomiast często spotykanymi jej symptomami są trudności $\mathrm{w}$ przypominaniu nieodległych zdarzeń, zapominanie podstawowych rzeczy, trudności w wykonywaniu zwykłych czynności dnia codziennego, problemy językowe, problemy z orientacją przestrzenną i czasową, osłabiona zdolność osądu, problemy z myśleniem abstrakcyjnym, gubienie rzeczy, wahania nastroju i zmiany w zachowaniu, zmiany osobowości, utrata inicjatywy. Objawy takie występują także w innych chorobach wieku dojrzałego, w konsekwencji których następuje zaburzenie świadomości i pamięci pacjenta [http://www. opieka-panaceum.pl/component/content/article/28-demencja-starcza. html]. Symptomy chorób wieku dojrzałego są podobne w początkowej fazie rozwoju, często są więc błędnie przypisywane do wieku, stresu, czy problemów życiowych pacjenta [Waldemar, Dubois, Emre, Georges, McKeith, Rossor, Scheltens, Tariska, Winblad, 2007; e1 - e26; http://www.alzheimers. org.uk/site/scripts/documents_info.php?documentID=100].

Wówczas, gdy występuje podejrzenie występowania określonej choroby wieku dojrzałego, diagnoza konkretyzująca schorzenie jest stawiana za pomocą testów oceniających zachowanie i zdolności kognitywne, a często wykonywane jest neuroobrazowanie. Z postępem choroby pojawiają się też takie objawy, jak: splątanie, drażliwość, agresja, trudności językowe oraz utrata pamięci długotrwałej. W następstwie pojawiających się dolegliwości chorzy wyłączają się z życia rodzinnego i społecznego. Funkcje życiowe zanikają powoli, stopniowo i etapami, co prowadzi w konsekwencji do śmierci. Jednakże niebezpieczne są pierwsze etapy choroby, $\mathrm{w}$ trakcie których postępuje nieujawniona, przebiega skrycie przez nieznany i zmienny okres, a jej postępy mogą trwać bez rozpoznania nawet 
przez lata. Średnia długość życia po zdiagnozowaniu wynosi 7 lat, a mniej niż 3\% chorych żyje z chorobą więcej niż 14 lat [http://www.alzheimersresearchuk.org/about-dementia/types-of-dementia/alzheimers-disease/ diagnosis; http://www.nia.nih.gov/alzheimers/topics/symptoms; Tabert, Liu, Doty, Serby, Zamora, Pelton, Marder, Albers, Stern, Devanand, 2005: 155-160; Mölsä, Marttila, Rinne, 1986: 103-107; Mölsä, Marttila, Rinne, 1995: 159-164]. W Polsce liczba osób dotkniętych schorzeniem stanowi ok. 250 tys. przypadków [http://www.poradnikzdrowie.pl/zdrowie/uklad-nerwowy/choroba-alzheimera-przyczyny-objawy-leczenie_33610.html]. Najczęściej występuje wśród osób dojrzałych. W 15-20 \% przypadków zależy od czynników genetycznych. Stwierdzono, że za jej postępowanie i nasilenie objawów odpowiedzialne są co najmniej cztery geny, umiejscowione na czterech chromosomach jądra komórkowego. Zauważono także, że chromosom 21, trudniący się produkcją białka, z którego powstaje szkodliwy beta-amyloid wpływa na osoby z zespołem Downa w taki sposób, że szczególnie często zapadają one po pewnym czasie na chorobę Alzheimera. Naukowcy z zakresu medycyny podkreślają także, że w rozwoju choroby najprawdopodobniej mogą odgrywać rolę również czynniki środowiskowe. Możliwe, że oddziaływanie metali (aluminium) na organizm i niski poziom hormonów mogą być czynnikami wyzwalającymi proces chorobowy [Hardy, Allsop, 1991: 383-388; Mudher, Lovestone, 2002: 22-26; Nistor, Don, Parekh, Sarsoza, Goodus, Lopez, Kawas, Leverenz, Doran, Lott, Hill, Head, 2007: 1493-1506; Lott, Head, 2005: 383-389; http://www. poradnikzdrowie.pl/zdrowie/uklad - nerwowy/choroba-alzheimera-przyczyny-objawy-leczenie_33610.html; http://www.choroba alzheimera.pl/ index.php5?strona=opischoroby; http://www.wiadomosci24.pl/artykul/demencja_starcza_jak_wyglada_zycie_chorych_i_ich_rodzin_226378.html; http://seniorzy.careexperts. pl/pamietaj-o-bliskich.html].

Konkretyzując cechy osoby, w stosunku do której analizowane jest zagadnienie zdolności do czynności prawnych w kontekście ważności oświadczenia woli, należy stwierdzić, że jest to co do zasady osoba w wieku dojrzałym, tj. powyżej 65 roku życia, u której występują symptomy chorobowe, jednakże osoba ta nie jest jeszcze zdiagnozowana lub jest we wczesnej fazie diagnostyki. Oznacza to, że nie występuje możliwość stwierdzenia na podstawie dokumentu, że określona osoba może być nieświadoma dokonywania określonych czynności prawnych bądź mogą występować u niej zaburzenia pamięci. Zagadnienie to jest ważne w kontekście prawnym, gdyż osoby takie znajdują się w przedziale wiekowym, w którym najczęściej dochodzi do 
porządkowania spraw formalnoprawnych związanych z życiem doczesnym takich, jak sporządzanie testamentów, zawieranie umów dożywocia, przenoszenie własności nieruchomości i ruchomości na osoby trzecie, czy też zawieranie umów z bankami o emerytury hipoteczne. Trudno jest przyjąć tezę, że u każdej osoby w wieku dojrzałym potencjalnie występują zaburzenia świadomości i pamięci. Teza taka byłaby błędna i mogłaby prowadzić do powstania krzywdy, np. w postaci dyskomfortu psychicznego osoby uznanej za nieświadomą. Natomiast, gdzie należy poszukiwać granicy umożliwiającej określenie, czy osoba taka jest świadoma dokonywanej czynności prawnej.

Wraz z rozwojem medycyny zwiększa się zobojętnienie społeczne na osoby starsze dotknięte schorzeniami wieku dojrzałego. Nierzadko zdarzają się stwierdzenia, np. „Babcia nie kontaktuje, nie ma o czym rozmawiać”. Kiedyś osoby starsze były otaczane wyjątkową opieką i szacunkiem. Głównie przyczyną takiego zachowania był schemat rodzin wielopokoleniowych zamieszkujących jedną nieruchomość, gdzie osoba starsza dożywała swych ostatnich dni w gronie osób sobie najbliższych. Jednocześnie pod względem prawnym osoby te, opiekując się seniorem rodu, chroniły majątek, czy posiadane prawa. Obecnie jesteśmy społeczeństwem kapitalistycznie młodym i standardowym zjawiskiem występującym $\mathrm{w}$ takim społeczeństwie jest kontraktowanie wszystkiego, w tym także opieki nad osobami starszymi. Często zleceniodawcy tracą kontrolę nad opiekującym się z tego powodu, że zaufali takiej osobie, a ta, wykorzystując ich zaufanie i brak bieżącego nadzoru, dokonała czynności prawnych z udziałem osoby oddanej pod opiekę z pokrzywdzeniem osób bliskich. Konformizm w tym zakresie może działać na szkodę.

Pod względem prawnym wydaje się, że istotnymi elementami czynności prawnej dokonywanej przez osobę wieku dojrzałego są autonomia woli i oświadczenie woli.

Elementami autonomii woli są [Radwański, 2008: 11]: swoboda dokonywania czynności prawnych, swoboda doboru strony czynności prawnej, swoboda zakończenia stosunku prawnego za zgodą jej podmiotów, swoboda kształtowania treści.

Zgodnie z teorią woli należy stwierdzić, że uzewnętrznienie wewnętrznej woli człowieka, zmierzające do wywołania skutków prawnych jest oświadczeniem woli. W teorii woli decydujące znaczenie stanowi jej wewnętrzny aspekt [Jędrzejewska, 1992: 10]. Odpowiedzią dezaprobującą teorię woli jest teoria oświadczenia. W myśl teorii oświadczenia, oświadczeniem woli jest samo zachowanie osoby, które w chwili podejmowania określonego zacho- 
wania pozwala wnioskować o określonej woli. Podnosi się przy tej koncepcji, że nieistotna jest wewnętrzna wola osoby [Jędrzejewska, 1992].

Jednakże, na gruncie polskiego prawa największe grono zwolenników wśród przedstawicieli doktryny zgromadziła orientacja obiektywna, która przyjmuje obiektywne ujęcie woli, przez co należy rozumieć zachowanie osoby działającej celem zaprezentowania swojej woli, nie zaś na jej woli wewnętrznej. Koncepcja ta jest uzasadniana w taki sposób, że akt wewnętrznej woli, który jest nieujawniony, może wprowadzać w błąd osoby, wobec których dokonywana jest czynność prawna [Gwiazdomorski, 1974: 57; Radwański, 1977: 37].

Następnie, aby oświadczenie woli mogło być przypisane osobie, która je wyraziła muszą być spełnione następujące przesłanki: świadomość oświadczającego i wywołanie zaufania stron czynności prawnej co do oświadczenia woli [Radwański, 2008: 21-23]. Warto jednak w tym zakresie odnieść się do stanowiska judykatury, gdyż w następstwie stosowania prawa często od wyroku sądu zależy ważność dokonywanych czynności prawnych. Zgodnie z treścią wyroku Sądu Najwyższego z dnia 7 maja 2014 r. [sygn. akt II CSK 481/13], „oświadczenie woli można określić jako zachowanie, z którego wynika - biorąc pod uwagę okoliczności w jakich zostało złożone, zasady współżycia społecznego oraz ustalone zwyczaje - wola dokonania określonej czynności prawnej. Przy ocenie zatem, czy i jakiej treści oświadczenie zostało złożone, decydujący powinien być jego odbiór zewnętrzny, a nie to, jaki wewnętrznie zamiar przyświecał w rzeczywistości składającemu oświadczenie”. Podobnie stwierdził Sąd Apelacyjny w Szczecinie w wyroku z dnia 24 lipca 2013 r. [ sygn. akt I ACa 287/13], w którym uznał, że „z oświadczeniem woli mamy do czynienia wówczas, gdy wewnętrzna wola podmiotu prawa cywilnego zostanie przez niego wyrażona, czyli uzewnętrzniona. Oświadczenie woli należy pojmować jako zewnętrzny przejaw wewnętrznej decyzji, rozumianej jako powzięcie woli wywołania określonych skutków prawnych. Podmiot składający oświadczenie woli musi zatem przejawiać chęć wywołania tym oświadczeniem określonych skutków prawnych. Skutek oświadczenia woli stanowi jego treść. Podmiot składający oświadczenie woli musi zatem obejmować swoją wolą określoną treść stosunku prawnego, który tym oświadczeniem zostaje wykreowany". Rozumienie pojęcia oświadczenia woli jest precyzowane również przez Sąd Apelacyjny w Szczecinie w wyroku z dnia 26 czerwca 2013 r. [sygn. akt I ACa 228/13], w którym podkreślono, że „oświadczeniem woli jest takie zachowanie osoby dokonującej czynno- 
ści prawnej, które ujawnia jej wolę w sposób dostateczny. Oświadczeniem woli jest przy tym wyłącznie zachowanie zmierzające do wywołania skutku w postaci powstania, zmiany lub ustania stosunku prawnego, czyli zachowanie mające wpływać na istnienie i treść uprawnień i obowiązków cywilnoprawnych (art. 56 kodeksu cywilnego). Złożeniem oświadczenia woli jest każde zachowanie człowieka zależne od jego woli, które może być przedmiotem obowiązku prawnego. Wśród źródeł takiego obowiązku wyróżnić można, zgodnie z tradycyjnym podziałem - ustawę, decyzję administracyjną oraz czynność prawną".

Oznacza to, że osoba, która dokonuje czynności winna mieć świadomość skutków prawnych dokonywanej czynności, zarówno w sferze uprawnień osobistych, jak i osoby, na rzecz której czynność prawna jest dokonywana. Osoba, składając oświadczenie woli, powinna w sposób klarowny określić, jaką czynność prawną zamierza dokonać oraz na czyją rzecz. Osoba, na rzecz której czynność prawna jest dokonywana, powinna się upewnić, co do prawidłowości rozumienia oświadczenia woli osoby dokonującej czynności prawnej.

Jednakże powstaje problem, w jaki sposób można stwierdzić, że osoba, z którą czynność prawna jest dokonywana, nie posiada świadomości. Nie zawsze można to stwierdzić od razu. Czy może zdarzyć się sytuacja, w której osoba z zaburzeniami świadomości i pamięci dokona ważnej czynności prawnej? Wydaje się, że odpowiedź w tym zakresie paradoksalnie jest twierdząca. Jeżeli druga strona czynności prawnej nie zauważy, bądź zatai, że osoba, z którą czynność prawna jest zawierana nie jest świadoma bądź cierpi na zaniki pamięci, czynność prawna jest ważna z chwilą zawarcia. Pozostaje natomiast roszczenie o jej unieważnienie, czy też uchylenie skutków prawnych. Wówczas jednak należy dostarczyć dowody na okoliczność stwierdzenia braku świadomości, czy pamięci osoby dokonującej czynności z pokrzywdzeniem siebie bądź osób bliskich. Stawiana teza znajduje uzasadnienie w orzeczeniach sądowych. Zgodnie z treścią wyroku Sądu Najwyższego z dnia 11 kwietnia 2006 r. [sygn. akt I CSK 175/05], „W wypadku gdy oświadczenie woli zostało ujęte w formie pisemnej, czyli wyrażone w dokumentach, to sens tych oświadczeń ustala się przyjmując za podstawę wykładni przede wszystkim tekst dokumentów, a przy ich interpretacji podstawowa rola przypada językowym, regułom znaczeniowym. Oznacza to, że teksty umów interpretowane według reguł językowych stanowią podstawę do przypisania im takiego sensu, jaki jest określony w regułach językowych. Przepis art. 60 kodeksu cywilnego nie uzasadnia przypisania czynnościom prawnym takiej 
treści, jaka nie wynika z tych czynności, ani też z ustawy, z zasad współżycia społecznego bądź z ustalonych zwyczajów. Wykładnia oświadczenia woli powinna bowiem zmierzać do ustalenia rzeczywistej treści czynności prawnej, nie może natomiast prowadzić do uzupełnienia złożonego oświadczenia o jego elementy wnioskowane przez stronę".

Dużym wsparciem dla ochrony interesu osoby dotkniętej zanikami świadomości i pamięci oraz bliskich takiej osoby jest dokonywanie czynności przed notariuszem. Obowiązkiem notariusza jest stwierdzenie, że osoba, która wobec niego dokonuje czynności prawnych na rzecz określonych osób, świadoma jest skutków prawnych takiej czynności, a przede wszystkim, czy osoba ta jest zdolna do dokonania czynności prawnych [Drozd, 2006: 71-82; Jacyszyn, 2006: 139-156; Pastuszko, 2006: 261-276]. Często wystarczy krótka rozmowa $\mathrm{z}$ osobą, $\mathrm{w}$ trakcie której zadawane są pytania wzajemnie powiązane [Kocur, Trendak, 2009: 136-140; Bolechała, Skupień, 2006: 48-55; Zieliński, 1982: 15-25; Fiutowski, 1976: 515-523]. Stanowisko takie jest zgodne z poglądami wyrażonymi przez judykaturę. Zgodnie z treścią postanowienia Sądu Najwyższego z dnia 13 stycznia 2005 r. [sygn. akt IV CK 428/04], „nie wykluczając możliwości posłużenia się przez notariusza projektem testamentu, spadkodawca powinien oświadczyć przed sporządzającym testament notariuszem swą ostatnią wolę, następnie przygotowany wcześniej projekt, jeżeli całkowicie odpowiada jego woli powinien mu być odczytany, w dalszej kolejności notariusz powinien upewnić się, przez potwierdzenie przez spadkodawcę zapisanej treści, czy spadkodawca dokładnie rozumie treść oraz znaczenie aktu i czy jest on zgodny z jego wolą. Sporządzony testament notarialny nie spełnia wymagań formalnych, jeśli spadkobierca przedstawia przyszłą treść testamentu notariuszowi, a inny notariusz posługujący się tym projektem procedurę sporządzania testamentu rozpoczął od odczytania tego projektu spadkodawcy i następnie został on tylko potwierdzony przez spadkodawcę". Podobnie, zgodnie z treścią uchwały Sądu Najwyższego z dnia 20 września 1968 r. [sygn. akt III CZP 85/68], „do ważności testamentu szczególnego $\mathrm{z}$ art. 952 kodeksu cywilnego konieczne jest ustne oświadczenie woli spadkodawcy. Nie wystarcza zatem ujawnienie woli w inny sposób, ani też podpisanie przez niego przygotowanego przez inną osobę pisemnego projektu testamentu". W tym zakresie istotne jest także postanowienie Sądu Najwyższego z dnia 18 lutego 1999 r. [sygn. akt I CKN 1002/97], w którym Sąd określa, że „wola testowania (animus testandi) polega na tym, że testator ma świadomość, iż podjęte przez niego zachowanie się stanowi sporządzenie testamentu, oraz ma wolę sporządzenia testamentu danej treści przez podjęcie 
tego właściwego zachowania”. Konkludując, podobnie jak ze wspomnianą na wstępie konstrukcją stołu, świadomość ludzka jest zbiegiem procesów kojarzenia zmysłów ze zdarzeniami. Jeżeli zamknie się oczy i nie występuje możliwość dotknięcia stołu, to czy on naprawdę istnieje? Jeżeli występują zaniki świadomości, czy pamięci, co ma miejsce najczęściej w przypadku początkowej fazy rozwoju chorób wieku dojrzałego, osoba dotknięta dolegliwościami może nie być świadoma dokonywanych czynności prawnych. Granica tej świadomości jest na tym etapie choroby jeszcze bardzo płynna i trudno jest jednoznacznie ustalić, czy w chwili dokonywania czynności prawnej osoba była świadoma, czy też nie. Wydaje się, że niezbędne jest posiłkowanie rozmową przed dokonaniem czynności prawnych, indywidualizacją osoby, jej sprawności intelektualnej, umiejętności kojarzenia faktów. Czy w takim przypadku pamięć i świadomość stanowią obligatoryjne elementy oświadczenia woli przy dokonywaniu czynności prawnych? Zgodnie z obowiązującym prawem, dla dokonania ważnej czynności prawnej wymagana jest zdolność i zdolność do czynności prawnych. Na pojęcie zdolności do czynności prawnej składa się m.in. sprawność intelektualna. Jeżeli jednak określona osoba nie ma ograniczonej zdolności do czynności prawnych, bądź nie jest całkowicie pozbawiona zdolności do czynności prawnych, np. w wyniku zastosowania instytucji ubezwłasnowolnienia całkowitego, czynności przez nią dokonywane będą ważne. Dopiero w wyniku wystąpienia $\mathrm{z}$ roszczeniem o unieważnienie czynności prawnej, bądź o uchylenie skutków prawnych czynności, będzie możliwe podniesienie zarzutu o braku świadomości, czy zaniku pamięci osoby dokonującej czynności prawnej. Zatem, czy samo stwierdzenie występowania zaburzeń pamięci i świadomości wystarczy, aby uznać czynność prawną za nieważną? Tu, niestety, też nie można jednoznacznie stwierdzić, co jest wystarczające do uznania braku świadomości osoby o dokonaniu czynności prawnej, czy skutku tej czynności. Dla ważności czynności prawnej istotna jest świadomość i oświadczenie woli składane w chwili dokonywania czynności prawnej. Istotny w konsekwencji będzie upływ czasu od chwili dokonania czynności prawnej do chwili podjęcia próby jej unieważnienia. Nie można przyjąć założenia, że osoba dokonująca na pewno nie była świadoma dokonywania czynności prawnej. Sytuację taką można ostatnio zauważyć przy testamentach sporządzanych przez osoby starsze, na mocy których część swego majątku przekazują fundacjom, czy na rzecz osób trzecich. Wówczas rodzina, przy braku aprobaty takiego postępowania, podejmuje czynności zmierzające do unieważnienia testamentu, jako sporządzonego przez osobę, która nie była świadoma jego dokonania. 
Należy jednak zawsze mieć na uwadze nie tylko ważność czynności prawnej dokonywanej przez osobę, u której występują zaniki świadomości i pamięci, ale przede wszystkim dobro takiej osoby. Osoba z zanikami świadomości, czy pamięci, czuje emocje, ale nie potrafi ich zidentyfikować. Osoba taka jest przekonana o urodzeniu syna, ale myli go nieraz z sąsiadem, co nie wpływa na jej uczucia. Dlatego przy dokonywaniu czynności prawnych ważna jest bezinteresowna pomoc w ich dokonaniu, zarówno w rozumieniu treści czynności, jak i ich skutków prawnych. Osoba z zanikami świadomości i pamięci wie, że jest, ale nie pamięta dokąd idzie - nie pozwólmy jej zaginąć.

\section{Bibliografia:}

Berchtold N/C., Cotman C. W. (1998), Evolution in the conceptualization of dementia and Alzheimer's disease: Greco-Roman period to the 1960s., "Neurobiology of Aging", nr 19 (3).

Bolechała F., Skupień E. (2006), Rozpoznanie depresji a zdolność do udziału w czynnościach procesowych, „Archiwum Medycyny Sądowej”, nr 1.

Brookmeyer R., Gray S., Kawas C. (1998), Projections of Alzheimer's disease in the United States and the public health impact of delaying disease onset, "American Journal of Public Health", nr 88 (9).

Brookmeyer R., Johnson E., Ziegler-Graham K., Arrighi H. M. (2007), Forecasting the global burden of Alzheimer's disease, “Alzheimer's and Dementia”, nr 3 (3).

Drozd E. (2006), Odpowiedzialność notariusza w wypadku nieważnej (bezskutecznej) czynności prawnej, (w:) R. Sztyk (red.), III Kongres Notariuszy Rzeczypospolitej Polskiej. Nowoczesny notariat w bezpiecznym państwie, Warszawa-Kluczbork, Wydawnictwo Stowarzyszenia Notariuszy RP.

Fiutowski J. (1976), Zdolność do czynności prawnych osób z zaburzeniami psychicznymi $w$ świetle analizy spraw o ubezwłasnowolnienie, „Psychiatria Polska”, nr 5.

Gwiazdomorski J. (1974), Próba korektury pojęcia czynności prawnej, „Prace z zakresu Prawa Cywilnego i Prawa na Dobrach Niematerialnych”, nr 364.

Hardy J., Allsop D. (1991), Amyloid deposition as the central event in the aetiology of Alzheimer's disease, "Trends on Pharmacological Sciences", nr 12 (10).

http://seniorzy.careexperts.pl/pamietaj-o-bliskich.html (dostęp: 23.04.2015).

http://wiadomosci.onet.pl/prasa/pieklo-zwane-alzheimer/cbedl (dostęp: 17.04.2015).

http://www.alzheimers.org.uk/site/scripts/documents_info.php?documentID=100 (dostęp: 22.04.2015).

http://www.alzheimersresearchuk.org/about-dementia/types-of-dementia/alzheimersdisease/diagnosis/ (dostęp: 23.04.2015). 
http://www.chorobaalzheimera.pl/index.php5?strona=opischoroby (dostęp: 23.04.2015). http://www.nia.nih.gov/alzheimers/topics/symptoms (dostęp: 23.04.2015).

http://www.opieka-panaceum.pl/component/content/article/28-demencja-starcza.html (dostęp: 22.04.2015).

http://www.poradnikzdrowie.pl/zdrowie/uklad-nerwowy/choroba-alzheimera-przyczyny-objawy-leczenie_33610.html (dostęp: 22.04.2015).

http://www.poradnikzdrowie.pl/zdrowie/uklad-nerwowy/choroba-alzheimera-przyczyny-objawy-leczenie_33610.html (dostęp: 22.04.2015).

http://www.wiadomosci24.pl/artykul/demencja_starcza_jak_wyglada_zycie_chorych_i_ ich_rodzin_226378.html (dostęp: 23.04.2015).

Jacyszyn J. (2006), Notariusz - zawodem zaufania publicznego, (w:) R. Sztyk (red.), III Kongres Notariuszy Rzeczypospolitej Polskiej. Nowoczesny notariat w bezpiecznym państwie, Warszawa-Kluczbork, Wydawnictwo Stowarzyszenia Notariuszy RP.

Jankovic J. (2008), Parkinson's disease: clinical features and diagnosis, Journal of Neurology, "Neurosurgery and Psychiatry" nr 79 (4).

Jędrzejewska A. (1992), Koncepcja oświadczenia woli w prawie cywilnym, Warszawa, Wydawnictwo Naukowe Scholar.

Kocur J., Trendak W. (2009), Psychiatryczno-sadowe kryteria oceny zdolności do świadomego albo swobodnego powzięcia decyzji i wyrażenia woli, „Archiwum Medycyny Sądowej”, nr 2.

Kordek R., Bratosiewicz-Wąsik J., Grams R., Liberski P. P. (2003), Pasażowalne encefalopatie gabczaste - choroby wywoływane przez priony, (w:) P. P. Liberski, M. J. Mossakowski (red.), Neurodegeneracje, t. 1, Biologia molekularna, podstawy strukturalne, choroby neurodegeneracyjne, Warszawa, Wydawnictwo CUN PAN.

Kozubski W., Liberski P. P. (red.), (2006), Neurologia. Podręcznik dla studentów medycy$n y$, Warszawa, Wydawnictwo Lekarskie PZWL.

Kozubski W., Liberski P. P. (2004), Stwardnienie zanikowe boczne, (w:) I. Hausmanowa -Petrusewicz, J. Rafałowska (red.), Choroby układu nerwowego, Warszawa, Wydawnictwo Lekarskie PZWL.

Liberski P.P. (2006), Choroba Creutzfeldta-Jakoba i inne choroby wywołane przez priony, (w:) W. Kozubski, P. P. Liberski (red.), Neurologia. Podręcznik dla studentów medycyny, Warszawa, Wydawnictwo Lekarskie PZWL.

Liberski P. P. (2003), Choroby wywołane przez priony, (w:) Z. Dziubek (red.), Choroby zakaźne i pasożytnicze, Warszawa, Wydawnictwo Lekarskie PZWL.

Lott I. T., Head E. (2005), Alzheimer disease and Down syndrome: factors in pathogenesis, "Neurobiology Aging", nr 26 (3).

Mölsä P. K., Marttila R.J., Rinne U. K. (1995), Long-term survival and predictors of mortality in Alzheimer's disease and multi-infarct dementia, "Acta Neurologica Scandinavica”, nr 91 (3).

Mölsä P. K., Marttila R.J., Rinne U. K. (1986), Survival and cause of death in Alzheimer's disease and multi-infarct dementia, "Acta Neurologica Scandinavica", nr 74 (2).

Mudher A., Lovestone S. (2002), Alzheimer's disease-do tauists and baptists finally shake hands?, "Trends in Neurosciences", nr 25 (1). 
Nistor M., Don M., Parekh M., Sarsoza F., Goodus M., Lopez G. E., Kawas C., Leverenz J., Doran E., Lott I. T., Hill M., Head E. (2007), Alpha- and beta-secretase activity as a function of age and beta-amyloid in Down syndrome and normal brain, "Neurobiology Aging", nr 28 (10).

Onari K., Spatz H. (1926), Anatomische Beiträge zur Lehre von der Pickschen umschriebene Grobhirnrinden-Atrophie ('Picksche Krankheit'), “Z Ges Neurol Psychiatrie“, nr 101 (1).

Pastuszko R. (2006), Obowiązek wyjaśniająco-doradczy notariusza a wysłuchanie stron czynności notarialnej, (w:) R. Sztyk (red.), III Kongres Notariuszy Rzeczypospolitej Polskiej. Nowoczesny notariat w bezpiecznym państwie, Warszawa-Kluczbork, Wydawnictwo Stowarzyszenia Notariuszy RP.

Postanowienie Sądu Najwyższego z dnia 13 stycznia 2005 r., sygn. akt IV CK 428/04, Legalis nr 84460.

Postanowienie Sądu Najwyższego z dnia 18 lutego 1999 r., sygn. akt I CKN 1002/97, Legalis 123600 .

Radwański Z. (2008), Opracowanie rozdziału I, (w:) Z. Radwański (red.), System Prawa Prywatnego, Prawo cywilne - część ogólna, t. 2, Warszawa, C. H. Beck Instytut Nauk Prawnych PAN.

Radwański Z. (1977), Teoria umów, Warszawa, Wydawnictwo Naukowe PWN.

Russell B. (2012), Problemy filozofii, Warszawa, Wydawnictwo Naukowe PWN.

Szczeklik A. (red.) (2005), Choroby wewnętrzne. Przyczyny, rozpoznanie i leczenie, t. 2, Warszawa, Wydawnictwo Medycyna Praktyczna.

Tabert M. H., Liu X., Doty R. L., Serby M., Zamora D., Pelton G. H., Marder K., Albers M.V., Stern Y., Devanand D.P. (2005), A 10-item smell identification scale related to risk for Alzheimer's disease, "Annals of Neurology", nr 58 (1).

Uchwała Sądu Najwyższego z dnia 20 września 1968 r., sygn. akt III CZP 85/68, OSNCP 1969 nr 6, poz. 102.

Waldemar G., Dubois B., Emre M., Georges J., McKeith I. G., Rossor M., Scheltens P., Tariska P., Winblad B. (2007), Recommendations for the diagnosis and management of Alzheimer's disease and other disorders associated with dementia: EFNS guideline, "European Journal of Neurology", nr 14 (1).

Wyrok Sądu Apelacyjnego w Szczecinie z dnia 24 lipca 2013 r., sygn. akt I ACa 287/13, Legalis nr 776455.

Wyrok Sądu Apelacyjnego w Szczecinie z dnia 26 czerwca 2013 r., sygn. akt I ACa 228/13, Legalis nr 776445.

Wyrok Sądu Najwyższego z dnia 11 kwietnia 2006 r., sygn. akt I CSK 175/05, Legalis nr 104931.

Wyrok Sądu Najwyższego z dnia 7 maja 2014 r., sygn. akt II CSK 481/13, Legalis nr 1048693.

Zajkowska J. M., Hermanowska-Szpakowicz T., Grygorczuk S., Kondrasik M., Pancewicz S. A., Czeczuga A., Ciemerych M. (2006), Neuroborelioza, „Polski Przegląd Neurologiczny", t. 2.1.

Zieliński A. (1982), Zdolność do dokonywania czynności procesowych przez osobę poddanq opiece, „Palestra”, nr 6/7. 


\section{SUMMARY}

\section{I do not remember where I was going, but I know that I am - about the legal capacity of persons with memory disorders and awareness}

The presence of memory disorders and memory consciousness is an increasingly widespread phenomenon of modern society. It is difficult to identify unambiguously, from which the abnormal phenomena may arise. Impaired memory and consciousness are most common in the elderly. Diseases which involve disturbances of memory, and consciousness are Alzheimer's, Parkinson's, Pick's disease, Huntington's chorea, neuroborreliosis, and Creutzfeldt - Jakob disease. The aim of the article is to point out the problem of understanding legal actions carried out by individuals with impaired memory and awareness, and an attempt to establish the border between important and unimportant activities because of the appearance of disorders of memory and consciousness.

\section{Keywords:}

legal action, legal capacity, awareness, memory, comprehension, legal effect 